\title{
Claire Joubert, ed., Le postcolonial comparé : anglophonie, francophonie
}

\section{Charles Forsdick}

\section{Q OpenEdition}

1 Journals

Electronic version

URL: https://journals.openedition.org/ces/5679

DOI: $10.4000 /$ ces. 5679

ISSN: 2534-6695

Publisher

SEPC (Société d'études des pays du Commonwealth)

\section{Printed version}

Date of publication: 1 April 2015

Number of pages: 105-107

ISSN: 2270-0633

\section{Electronic reference}

Charles Forsdick, "Claire Joubert, ed., Le postcolonial comparé : anglophonie, francophonie",

Commonwealth Essays and Studies [Online], 37.2 | 2015, Online since 13 April 2021, connection on 17 July 2021. URL: http://journals.openedition.org/ces/5679 ; DOI: https://doi.org/10.4000/ces.5679

This text was automatically generated on 17 July 2021.

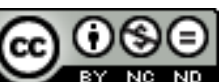

Commonwealth Essays and Studies is licensed under a Licence Creative Commons Attribution - Pas d'Utilisation Commerciale - Pas de Modification 4.0 International. 


\title{
Claire Joubert, ed., Le postcolonial comparé : anglophonie, francophonie
}

\author{
Charles Forsdick
}

\section{REFERENCES}

Claire Joubert, ed. Le postcolonial comparé : anglophonie, francophonie. Saint-Denis: PU de Vincennes, 2014. 288 p. ISBN paper: 978-2-84292-407-2. €20

1 Le Postcolonial comparé is a welcome addition to recent work in the postcolonial field, actively illustrating important developments in the area that have become more and more apparent in the second decade of the twenty-first century. The collection reflects the urgency of two key research agendas. On the one hand, it reveals the increasingly constructive ways in which an engagement with postcolonialism in the Frenchspeaking world has moved beyond initial controversy (and even antagonism) towards much more enabling dialogues across national and linguistic boundaries. On the other, the volume contributes actively to what Emily Apter called some years ago the "complit-ization" of postcolonial criticism, at once challenging the alinguistic assumptions evident at times in postcolonialism's Anglophone biases, but also indicating what might be feasible once the field has been opened up to a wider range of languages, cultures and historical contexts. As such, the collection can be seen as a return to the largely forgotten origins of postcolonial criticism, in the militant comparatism (cast as "counterpoint") of Edward Said (whose links to Fanon and Césaire, and ultimately partial engagement with the Francosphere, are studied in this volume by Dominique Combe) and in the call of pioneers such as Ashcroft, Griffiths and Tiffin for what they describe as an "inherently comparative methodology and the hybridized and syncretic view of the modern world which this implies." At the same time, as chapters such as J. Dillon Brown's on the institutional context of Caribbean literatures in English make clear, the volume illustrates the extent to which a sustainably comparatist approach 
depends on translation, understood as an inter-linguistic, intercultural vehicle for the circulation of new ideas.

2 The foreword describes the "ideological and epistemological frictions" ${ }^{\text {generated by }}$ the cross-linguistic and cross-disciplinary tensions evident in genuinely open postcolonial criticism. Focussing in particular on Anglophone and Francophone critical traditions, the editors underline the importance of different linguistic and intellectual histories, and of the ways in which these histories have played out in a post/colonial frame. Claire Joubert's comprehensive overview chapter, with which the collection opens, underlines the linguistic, geographical and historical specificity of postcolonialism, reflecting on the ways in which an inaugural Indian subcontinental model has been slowly replaced by a Caribbeanization of the field (a tendency particularly evident in Michael Dash's contribution, in which he outlines a critical practice centred on the Caribbean negotiating a path between a "narrow nationalism" 2 and an "abstract universalism." ${ }^{3}$ Joubert's particular focus is on transcolonial approaches, and also on the increasing prevalence of plurinational co-colonialism. Reminding readers of the pitfalls of an approach to postcolonial subjects that privileges the discursive at the expense of the linguistic, she outlines an agenda to which subsequent contributors are invited to respond: "the hypothesis of the transcolonial reminds us that the political sphere filters through languages and between languages." 4 As an indication of approaches to postcolonialism that adopt such a genuinely internationalized and internationalist frame, Joubert cites the work of Robert Young and in one of several contributions to the volume by scholars outside the Francophone academy, it is Young himself who decries the tendency of scholarship (and its institutional supports) to treat literature according to fixed linguistic divisions, "following a jealously guarded apartheid system." ${ }^{5}$ His conception is of a postcolonial critical practice, open to marginalized voices, which not only challenges the reductive equation of a nation with a single language, but also acknowledges the constant interplay between linguistic traditions both within and beyond the nation. As such, Young calls for a decolonization of the assumptions underpinning scholarly practices that, at best, tend towards the linguistically mute, or at worst replicate the complicity of language and colonial ideology as visible here in Alice Goheneix-Polanski's study of "the civilizing argument in the French language's colonial doctrine."

3 Central to the postcolonial comparatism towards which both Joubert and Young gesture is an awareness of differing scholarly paradigms and practices, and Jean-Marc Moura provides a study of what he calls the emergence of pluralized "Francophone postcolonialisms," elements of a tripartite project linked to the globalization of literary history, the development of linguistically inclusive regional literary histories, and the elaboration of a more internationalized theory of literary criticism. Christine Lorre-Johnston provides an exemplary overview of the types of exchange that such an approach might imply. She presents a comprehensive survey of "whiteness studies," tracking its emergence and evolution, and giving a detailed reflection of its impact in Canadian literary criticism. Her conclusions suggest that such a critical approach developed in the light of the problematization of whiteness in the context of Anglophone and Francophone Canada - might be suggestive of new comparative practices, and would also permit fresh engagement with parts of the Francophone world itself (most notably perhaps the Caribbean). 
4 The volume as a whole presents comparatism both within and beyond the Francosphere, demonstrating the potential of postcolonial approaches to illuminate intra-linguistic/intra-Francophone connections that have previously attracted little attention. For instance, through bringing together the biographies of Josephine Baker and Mayotte Capécia, in a co-authored closing chapter, Myriam Cottias and Madeleine Dobie deploy transcolonial comparatism to explore questions of race and gender. Concentrating on a specifically Francophone frame, Martin Mégevand takes a topic central to French history and culture - Terreur - and explores this in the light of Elleke Boehmer and Stephen Morton's work on the subject of terror and the postcolonial. Adopting three axes (confrontation, appearance, commemoration) ${ }^{8}$ and focussing on the theatre, he reveals the ways in which a postcolonial approach to terror contributes considerably to understandings of genericity and poetics.

5 The second half of the volume returns, however, to the opening emphasis on the ways in which the Caribbean, as a quintessential translation zone, might play a key role in a comparatist postcolonialism - or a postcolonial comparatism. Chapters on Nancy Morejón (by Sandra Monet-Descombey Hernández) and José Martí (by Claire Hennequet) open the volume's purview hemispherically, to North and South America, drawing in Hispanophone material at the same time; Kathleen Gyssels, in a study of anthologies by Léon-Gontran Damas and Albert Helman, extends the range to the Guyanas as sites of exploration of the Glissantian "Tout-Monde."

6 Le Postcolonial comparé is a highly suggestive volume, demonstrating the critical benefits of a continued prying open of the postcolonial field along translingual, transcultural and transcolonial lines. As the contributions to the volume make clear, such a manoeuvre depends not only on translation and an awareness of differing intellectual trajectories, but also on a willingness to understand and harness the creative frictions to which the foreword alludes. The potential outcome of such an approach is underlined by Moura: "a 'postcolonial,' possibly global vision which could be the basis of a plurilingual group of 'literatures of the South,' rising from historical considerations and not simply from a linguistic community." The volume suggests that such an active dialogue, bridging intellectual, conceptual and linguistic divides, is becoming possible.

\section{NOTES}

1. The original reads as follows: "frictions idéologiques et épistémologiques."

2. "nationalisme étroit."

3. "universalisme abstrait."

4. "l'hypothèse du transcolonial rappelle que le politique passe par les langues, et passe entre les langues" (38).

5. "selon un système d'apartheid jalousement gardé" (46).

6. "l'argument civilisateur dans la doctrine coloniale de la langue française."

7. "postcolonialismes francophones" (87).

8. "confrontation," “comparution," "commémoration." 
9. "une vision 'postcoloniale' voire globale qui pourrait fonder un ensemble plurilingue de 'littératures du Sud,' à partir de considérations historiques et non plus seulement à partir d'une communauté linguistique" (93).

\section{AUTHORS}

\section{CHARLES FORSDICK}

Charles FORSDICK is James Barrow Professor of French at the University of Liverpool and AHRC Theme Leadership Fellow for "Translating Cultures." He has published on travel writing, colonial history, postcolonial literature and the cultures of slavery. He is also a specialist on Haiti and the Haitian Revolution, and has written about representations of Toussaint Louverture. His publications include Victor Segalen and the Aesthetics of Diversity (OUP, 2000) and Travel in Twentieth-Century French and Francophone Cultures (OUP, 2005). 